\title{
ART1 Silencing Enhances Apoptosis of Mouse CT26 Cells via the PI3K/Akt/NF-KB Pathway
}

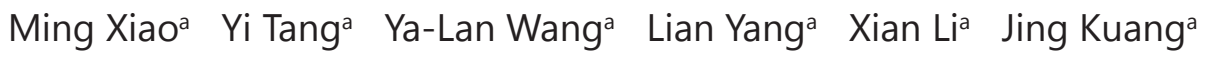 \\ Guang-Lin Songa \\ ${ }^{a}$ Department of Pathology, Molecular Medicine and Cancer Research Center, Chongqing Medical \\ University, Chongqing, China
}

Key Words

ART1 • shRNA $・$ Apoptosis $・$ PI3K/Akt pathway $・$ Bcl-2

\begin{abstract}
Background/Aims: Colorectal carcinoma is one of the most common cancers world-wide, with high morbidity and mortality rates. Arginine ADP-ribosyltransferase 1(ART1) is an important ecto-ADP-ribose transferase and has been proven to be intimately involved in a number of biological processes. However, the influence of ART1 on survival and apoptosis of colorectal carcinoma cells and the potential mechanism of action of ART1 remain uncharacterized. Methods: ART1 was silenced via lentiviral vector-mediated short hairpin RNA (shRNA) in CT26 colon carcinoma cells, and cisplatin (CDDP) was applied to induce apoptosis. Survival and apoptosis rate of CT26 cells was assessed by CCK8 assay, flow cytometry and Hoechst 33342 staining. Expression and activity of signaling proteins were detected by Western blot. Results: ART1 knockdown enhanced the inhibition of cell survival and increased the apoptosis induced by CDDP. Furthermore, the reduced survival rate correlated with reduced levels of phos-Akt $\mathrm{T}_{\mathrm{Th} 308}$ and phos-IKB $\alpha$ and reduced NF-KB p65 nuclear translocation. A decline in Bcl-2 and $\mathrm{Bcl}-\mathrm{xl}$ expression and an increase in Bax expression may explain the enhanced apoptosis. Conclusion: This study provides a molecular mechanism for the function of ART1 in colorectal carcinoma and defines a potential therapeutic target for the enhanced treatment of this prominent world-wide disease.

Copyright (c) 2013 S. Karger AG, Basel
\end{abstract}

\section{Introduction}

Colorectal carcinoma is a major cause of cancer death in affluent countries [1]. During the development of colorectal carcinoma, cells undergo variant clonal proliferation and escape from apoptosis. Therefore, enhanced apoptosis provides one potential method 


\section{Cellular Physiology and Biochemistry}

Cell Physiol Biochem 2013;32:1587-1599

\begin{tabular}{l|l}
\hline DOI: $10.1159 / 000356595$ & (C) 2013 S. Karger AG, Basel
\end{tabular}

Published online: December 03, $2013 \quad$ www.karger.com/cpb

Xiao et al.: ART1 Silencing Enhances Apoptosis of CT26

to suppress tumor survival [2]. Based on this notion, attempts to find specific targets to sensitize colorectal cancer cells to apoptosis induction could provide a valuable approach for suppressing tumor survival during anti-tumor treatment.

Mono ADP-ribosylation is a covalent chemical modification process by which a single moiety of ADP-ribose of nicotinamide adenine dinucleotide (NAD+) is attached to specific amino-acid residues of acceptor proteins. This reaction was originally identified in bacterial pathogens [3]. Subsequently, endogenous mammalian mono (ADP-ribosyl) transferases were characterized as a family of enzymes that are related to bacterial toxins $[4,5]$. These enzymes include ecto-ADP-ribose transferases (ecto-ARTs) and a few intracellular enzymes which could catalysis mono-ADP-ribosylation but with almost undefined structure [6-13]. The ecto-ARTs include seven members, designated as ART1 through ART7. Among the seven, ART1, 2, 3 and 4 are anchored in the outer leaflet of the plasma membrane via a glycosylphosphatidylinositol tail, whereas ART5, 6, and 7 are secreted to the extracellular space $[5,14]$. The ART2 protein is not expressed in humans due to a premature stop codon within its gene [15]. ART1, 2, and 5 have the signature R-S-EXE sequence of arginine-specific mono-ARTs in their putative catalytic sites; however, ART3 and 4 lack the R-S-EXE motif, and it is unclear whether or not they are active [5]. Hence, ART1 seems to be the most important ecto-ART [16].

Previous studies have shown that ART1 is predominantly expressed in skeletal and cardiac muscle $[5,17]$; however, research from our team determined that ART1 also is expressed on colonic epithelia [18]. ART1 appears to have an intimate role in many biological processes. Several studies have demonstrated that ART1 plays a crucial role in anti-inflammatory signaling and the cytokine secretion capacity of the respiratory tract epithelial cell during inflammation $[19,20]$. Furthermore, previous research by our team showed that ART1 is over-expressed in colorectal carcinoma tissues of human beings and has a positive correlation with VEGF and integrin $\alpha \mathrm{V} \beta 3$ expression, indicating that ART1 may be associated with the angiogenesis of colorectal carcinoma [18]. In a separate study, we demonstrated that ART1 silencing efficiently inhibits the proliferation of CT26 cells [21]. Based on the effects of ART1 on biological processes in tumor and non-tumor diseases which have been found, we speculated that ART1 may regulate apoptosis in colorectal carcinoma cells, thus providing a potential method to assist in promoting the death of tumor cells via ART1 silencing.

The PI3K/Akt signal transduction pathway plays a critical role in the activation of a number of well-established pathways towards suppressing apoptotic function, including the nuclear transcription of NF- $\mathrm{KB}$ and the modulated expression of the Bcl-2 protein family [22, 23]. However, it has not been determined whether ART1 can affect survival and apoptosis in colorectal carcinoma cells and whether this process might involve the activation of the $\mathrm{PI} 3 \mathrm{~K} / \mathrm{Akt} / \mathrm{NF}-\mathrm{\kappa B}$ pathway or the increased expression of apoptosis associated Bcl-2 family proteins.

In this study, to determine the effect of ART1 silencing on the survival and apoptosis of colon cancer cells, we silenced ART1 in CT26 cells via transfection of a lentiviral-based ART1-shRNA, and then we applied Cisplatin (CDDP) to induce apoptosis in the ART1 silenced cells[24, 25]. CDDP is an accepted apoptosis inducer which induces apoptosis via both death receptor pathway and mitochondrial pathway[26]. Given the importance of the Akt pathway in apoptosis, we tested the hypothesis that the effects of ART1 silencing may be associated with the inhibition of the PI3K/Akt pathway and the downstream interference of NF-кB activation and Bcl-2 expression.

\section{Materials and Methods}

Reagents

The CT26 cell line was kindly provided by Professor Wei YQ, SiChuan University. CT26 cells transfected with ART1-shRNA (ART1-shRNA) (interference sequence: GCCAACAAAGTATACGCGGAT ) and non- 


\section{Cellular Physiology and Biochemistry}

Cell Physiol Biochem 2013;32:1587-1599

Xiao et al.: ART1 Silencing Enhances Apoptosis of CT26

target shRNA (control-shRNA) (interference sequence: TTCTCCGAACGTGTCACGT) have been previously established [27]. Phos-IкB $\alpha$ antibody was purchased from Cell Signaling Technology, Inc. (MA, USA); ART1 antibody was purchased from Santa Cruz Biotechnology (CA, USA); Bax, Akt, phos-Akt Thr ${ }^{308}$, NF- $\mathrm{B}$ p65 and histone-H2B antibodies were purchased from Bioworld, Inc (MN, USA); Bcl-2 and Bcl-xl antibodies were purchased from Ebioscience (CA, USA); $\beta$-actin antibody was purchased from Boster Bioengineering Co. Ltd. (Wuhan, China); and ART1 antibody was purchased from Santa Cruz Biotechnology, Inc. (CA, USA). Cisplatin (CDDP), from Sigma-Aldrich Co. (MO, USA), was diluted in RPMI-1640 medium at a final concentration of $1 \mathrm{mM}$ and stored at $4^{\circ} \mathrm{C}$ in darkness. LY294002, from Cell Signaling Technology, Inc. (MA, USA), was diluted in DMSO.

\section{Cell culture}

CT26 cells and the ART1-shRNA and control-shRNA cell lines were cultured in RPMI-1640 medium (Hyclone, Logan, UT, USA) supplemented with 10\% fetal bovine serum (FBS), $100 \mathrm{U} / \mathrm{ml}$ penicillin and 100 $\mu \mathrm{g} / \mathrm{ml}$ streptomycin (Hyclone) at $37^{\circ} \mathrm{C}$ in a $5 \% \mathrm{CO}_{2}$ incubator.

\section{Flow cytometry analysis}

Flow cytometry analysis with an Annexin V-PE/7-AAD apoptosis detection kit (Tianjin Sungene Biotech) was used to determine the apoptosis ratio within each group of CT26 cells. The cells were seeded onto 6-well plates at a density of $1 \times 10^{5}$ cells/well and allowed to adhere overnight. Then, the cells were treated with CDDP at a concentration of $30 \mu \mathrm{M}$ for $48 \mathrm{~h}$. Adherent and suspension cells were harvested, pelleted by centrifugation (2,000 rpm for $5 \mathrm{~min}$ ), washed twice with $1 \times \mathrm{PBS}$ and resuspended in binding buffer. The cells were combined with PE-conjugated Annexin-V and 7-AAD, incubated for $30 \mathrm{~min}$ at room temperature in darkness and analyzed by flow cytometry (Becton Dickison). All experiments were conducted at least three times.

\section{Hoechst 33342 staining}

Formation of apoptosis bodies and condensed nuclei in the three groups of CT26 cells were quantified with Hoechst 33342 staining. Cells were seeded in six-well plates at a density of $1 \times 10^{5}$ cells $/$ well and treated with $30 \mu \mathrm{M}$ CDDP for $48 \mathrm{~h}$. Adherent cells and suspension cells were harvested, washed twice with chilled $1 \times$ PBS and resuspended, then $5 \mu \mathrm{l}$ of Hoechst 33342 were add to each sample. The cells were incubated for $30 \mathrm{~min}$ at room temperature in darkness, and stained nuclei were visualized under fluorescent optics. The percentage of apoptotic cells, also referred to as the apoptotic ratio (AR), was calculated using the formula: $\mathrm{AR} \%=$ apoptotic cells $(\mathrm{A}) /$ total cell count $(\mathrm{T})] \times 100$. Approximately 10 images of each sample were acquired and analyzed in three different experiments.

\section{CT26 cell survival assays}

CT26 cells and its derivative cell lines were seeded in 96-well plates at $1 \times 10^{4}$ cells $/$ well. After adherence overnight, the cells were exposed to increasing concentrations $(1,5,10,20,30,40,50,60,70 \mu \mathrm{M})$ of CDDP for $24 \mathrm{~h}$ or $10 \mu \mathrm{M}$ for 24 h, 48 h or 72 h. Cell Counting Kit-8 (CCK8, KeyGen Biotechnology, Nanjing $\mathrm{P}$ R China) was added, and plates were incubated for $4 \mathrm{~h}$ at $37^{\circ} \mathrm{C}$. The absorbances (optical densities) were recorded with a universal microplate reader (Bio-Tek) at $450 \mathrm{~nm}$. The assays were repeated at least three times.

\section{Protein extract preparation}

Nuclear protein extract and total protein extract were prepared using whole-cell protein lysis buffer (Beyotime) and nuclear protein lysis buffer (Beyotime) containing protease and phosphatase inhibitor (1mM phenylmethylsulfonyl fluoride and $1 \mathrm{mM}$ sodium orthovanadate ), respectively. In brief, for total protein extract, $5 \times 10^{6}$ cells were washed twice with $1 \times$ PBS. Then the suspensions were centrifuged for 5 $\min$ at 5,000 rpm at $4^{\circ} \mathrm{C}$. The supernatant was discarded and the pellets were resuspended in $100 \mu \mathrm{l}$ cell lysis buffer for $30 \mathrm{~min}$ on ice. Total protein extract was recovered after centrifugation for 5 min at 12,000 $\mathrm{rpm}$ and $4^{\circ} \mathrm{C}$. For nuclear protein extract, cells were resuspended in $200 \mu \mathrm{l}$ cytoplasm protein lysis buffer A, centrifuged for $5 \mathrm{~min}$ at 5,000 rpm at $4^{\circ} \mathrm{C}$ and placed on ice for $15 \mathrm{~min}$. Then $10 \mu \mathrm{l}$ cytoplasm protein lysis buffer B was added, and the mixture was vortexed for $10 \mathrm{sec}$ and centrifuged for $10 \mathrm{~min}$ at 12,000 $\mathrm{rpm}$ and $4^{\circ} \mathrm{C}$. The supernatant containing the cytoplasmic fraction was carefully discarded and the pellet 


\section{Cellular Physiology and Biochemistry}

Cell Physiol Biochem 2013;32:1587-1599

\begin{tabular}{l|l}
\hline DOI: $10.1159 / 000356595$ & (C) 2013 S. Karger AG, Basel
\end{tabular}

Published onlıne: December 03, $2013 \quad$ www.karger.com/cpb

Xiao et al.: ART1 Silencing Enhances Apoptosis of CT26

containing the nuclear fraction was resuspended in $50 \mu \mathrm{l}$ of nuclear protein lysis buffer for $30 \mathrm{~min}$ on ice with occasional vortexing. Nuclear extracts were recovered after centrifugation for $30 \mathrm{~min}$ at 14,000 rpm and $4^{\circ} \mathrm{C}$

\section{Western blot analysis}

Protein concentrations were evaluated using BCA protein assay reagent (Beyotime). Protein (30 $\mu \mathrm{g}$ protein/lane) and prestained molecular weight markers were separated on 10\%-15\% SDS-polyacrylamide gels in a minigel apparatus (Mini-PROTEAN II, Bio-Rad) and transferred to nitrocellulose membranes $(0.42$ $\mu \mathrm{m}$ pore size, Bio-Rad). The membranes were then incubated for $1 \mathrm{~h}$ in a blocking solution containing $5 \%$ nonfat milk in Tris-buffered saline containing 0.1\% Tween-20 (TBST) for unphosphorylated protein or a blocking solution containing 5\% BSA in TBST for phosphorylated proteins. After incubation, the membranes were washed in TBST and incubated overnight at $4^{\circ} \mathrm{C}$ with ART1, histone-2B, phos-Akt Thr ${ }^{308}$ or phos -

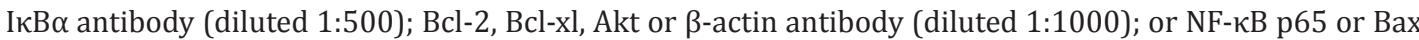
antibody (diluted 1:1500). The next day, the membranes were washed three times with TBST and incubated with secondary antibody (peroxidase-conjugated goat anti-rabbit or rabbit anti-mouse IgG) at a dilution of 1:1000 for $2 \mathrm{~h}$ at room temperature. Then, blots were washed three times with TBST, visualized with enhanced chemiluminescence reagent (Pierce Biotechnology) and exposed to the gel formatter (BioRad). The intensity of each band was analyzed with Quantity One software. Similar protein extraction and Western blot steps were followed for CT26 cells combined with $30 \mu \mathrm{M}$ CDDP and/or $30 \mu \mathrm{M}$ LY294002. All experiments were performed in triplicate.

\section{Statistical analysis}

The quantitative data were reported as mean \pm standard deviation (SD). Statistical analysis was performed by one-way ANOVA and a Student's t-test using the SPSS 11.5 software package. All of the $\mathrm{P}$-values were two-sided, and $\mathrm{P}<0.05$ was considered to indicate a statistically significant difference.

\section{Results}

ART1 silencing enhances CT26 cell apoptosis induced by CDDP

To determine whether silencing of ART1 affects CDDP induced apoptosis of CT26 colon carcinoma cells, we performed flow cytometry using Annexin V-PE/ 7-AAD staining. CDDP induced apoptosis in untransfected cells $(49.74 \pm 4.68 \%$ apoptosis) and control-shRNA cells (52.38 $\pm 6.13 \%$ apoptosis). However, this effect was even more striking in ART1-shRNA cells, with $73.98 \pm 5.19 \%$ apoptosis ( $\mathrm{P}<0.05$ compared to the control groups) (Fig. 1 ). Furthermore, apoptotic bodies and chromatin condensation were observed in all three groups of CDDPtreated cells by Hoechst33342 staining; however more cells bearing these hallmarks of apoptosis were observed in the ART1-shRNA cells than in the other two groups. Consistent with the Annexin/7-AAD staining, the apoptosis rates of untransfected, control-shRNA and ART1-shRNA cells based on the number of cells with condensed nuclei, were $46.88 \pm 8.45 \%$, $50.02 \pm 5.70 \%$ and $75.51 \pm 11.54 \%$, respectively ( $<<0.05$ for the ART1-shRNA cells compared with the other two groups) (Fig. 2). These results verify that silencing of ART1 leads to enhanced levels of apoptosis in CT26 cells following CDDP treatment.

ART1 silencing decreases the survival rate of CT26 cells following CDDP treatment

To determine whether the enhanced apoptosis in ART1 knockdown CT26 cells following CDDP treatment is reflected at the level of cell survival, we performed a CCK8 colorimetric assay. The survival rate of the ART1-shRNA group was found to be substantially lower than the other two groups at a range of CDDP concentrations $(1,5,10,20,30,40,50,60$, and 70 $\mu \mathrm{M})$ and at three time intervals $(24 \mathrm{~h}, 48 \mathrm{~h}$, and $72 \mathrm{~h})(\mathrm{P}<0.05)$. As expected, there were no significant differences in the survival rate between the untransfected and control-shRNA groups ( $\mathrm{P}>0.05$ ) (Fig. 3). These results confirm that silencing of ART1 leads to reduced cell survival in CT26 cells following CDDP treatment. 


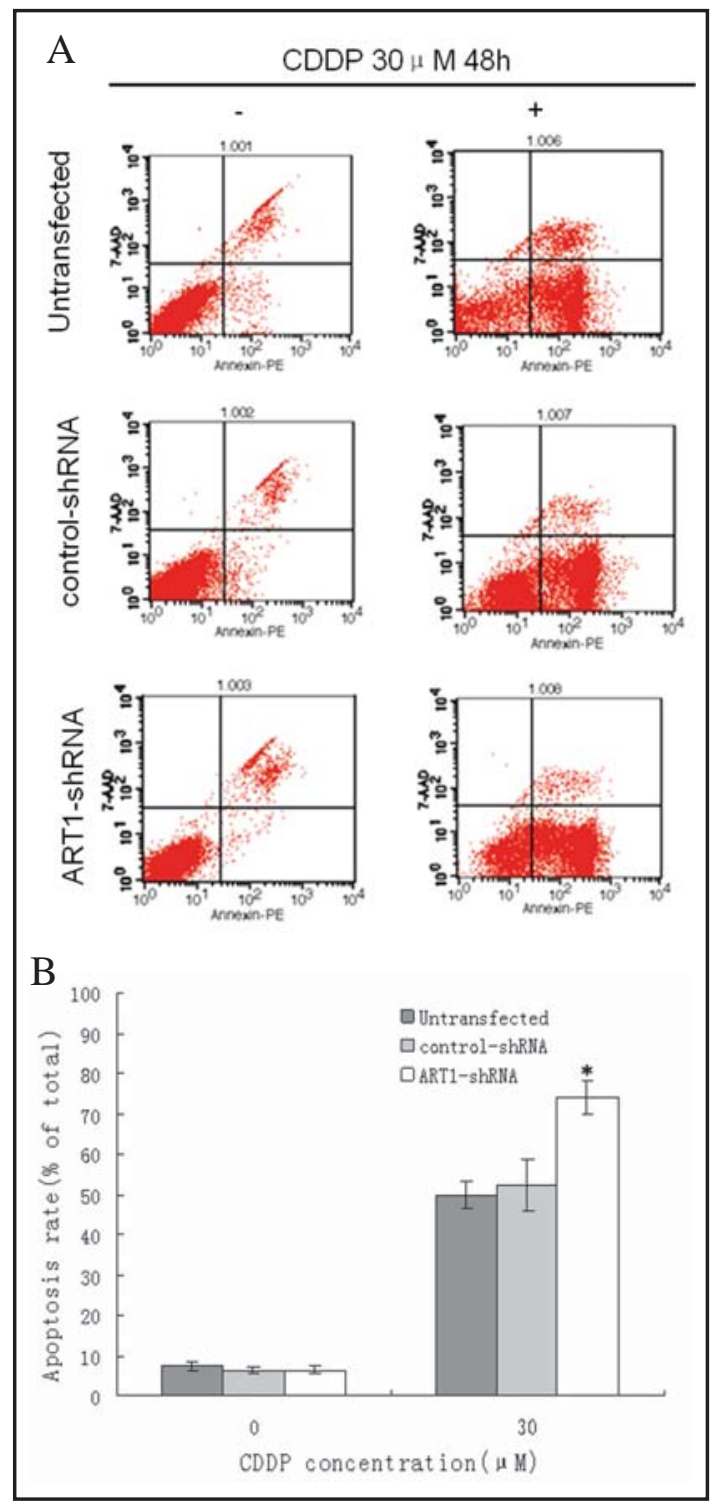

Fig. 1. ART1 silencing enhances CDDP-induced apoptosis of CT26 cells as assessed by flow cytometry. (A) CDDP cause striking apoptosis in untransfected, control-shRNA and ART1-shRNA CT26 cells as assessed by flow cytometry analysis of Annexin $\mathrm{V}$ PE/7-AAD. (B) Quantification of the apoptosis rate from panel A yielded $49.74 \pm 4.68 \%$ positivity for untransfected cells, $52.38 \pm 6.13 \%$ for control shRNA cells and $73.98 \pm 5.19 \%$ for ART1-shRNA cells. The apoptosis rate for ART1-shRNA CT26 cells is statistically increased compared with other two groups. $(* \mathrm{P}<0.05)$. Results are representative of three independent experiments.

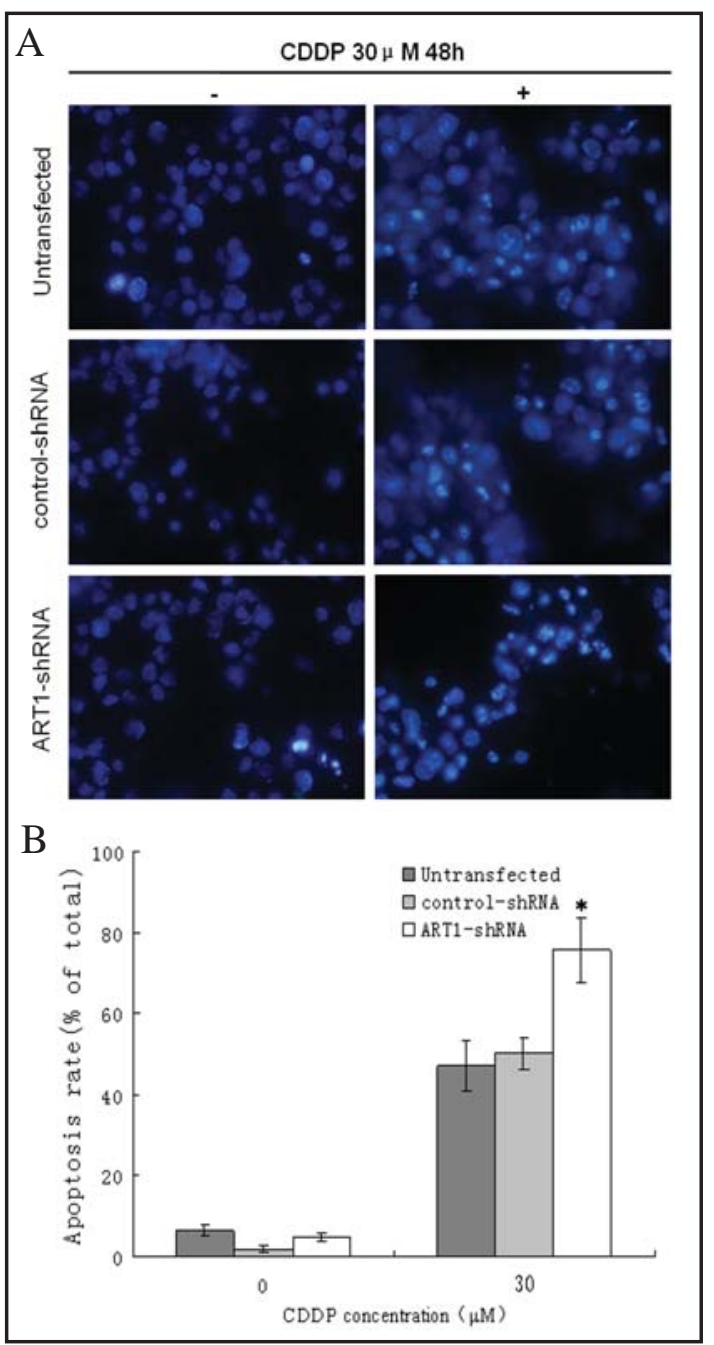

Fig. 2. ART1 silencing enhances CDDP-induced apoptosis of CT26 cells as assessed by Hoechst 33342 staining. (A) Representative images of untransfected, control shRNA and ART1-shRNA cells before or following $48 \mathrm{~h}$ treatment with $30 \mu \mathrm{M}$ CDDP. The appearance of apoptotic bodies and condensed chromatin in CDDP-treated cells is indicative of increased apoptosis. (B) Quantification of the apoptosis rate for the treatments from panel A. Results represent the mean +/- SD of approximately 10 images from three independent experiments. Based on the average number of cells with condensed nuclei, the apoptosis rates following CDDP treatment are $46.88 \pm 8.45 \%$ for untransfected cells, $50.02 \pm 5.70 \%$ for control-shRNA cells and $75.51 \pm 11.54 \%$ for ART1-shRNA cells. The number of cells with condensed nuclei is statistically greater for the ART1-shRNA CT26 cells compared with the other two groups $\left({ }^{*} \mathrm{P}<0.05\right)$.

\section{ART1 silencing reduces Akt phosphorylation and activation of $N F-\kappa B p 65$}

To determine whether ART1 knockdown affects the activation of the PI3K/Akt pathway, the expression of Akt and its activated form, phos-Akt $\operatorname{Thr}^{308}[28,29]$, was investigated by 


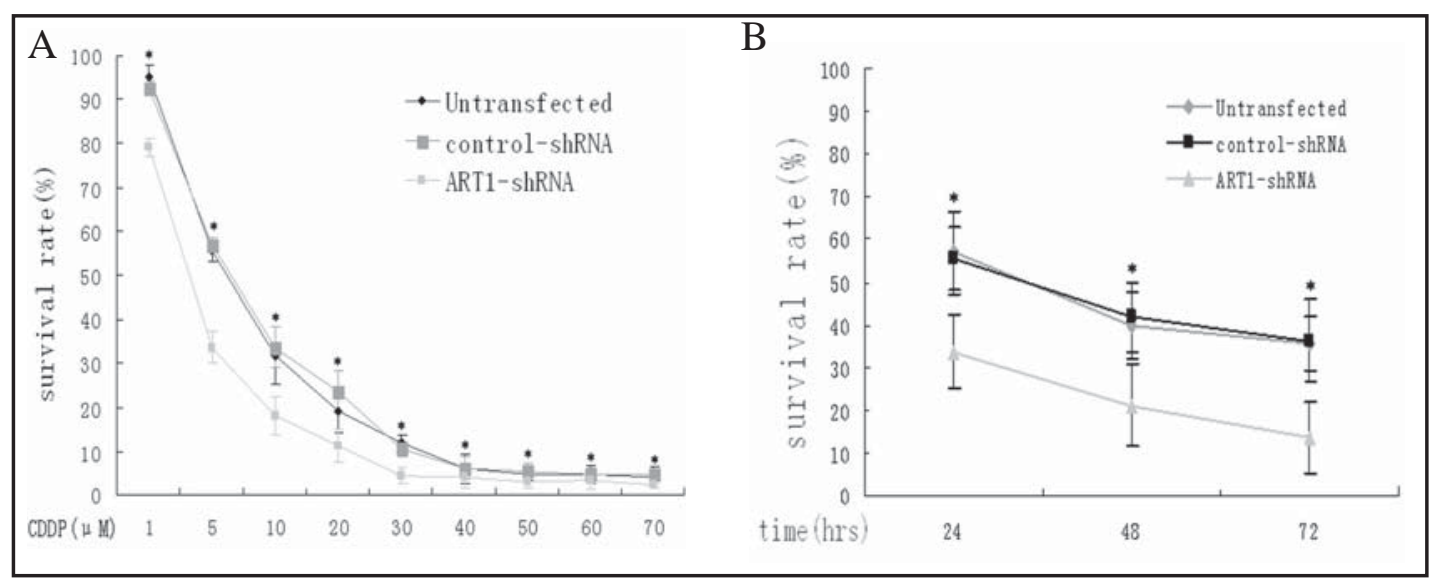

Fig. 3. ART1 silencing enhances the survival rate of CT26 cells. Untransfected, control-shRNA and ART1shRNA CT26 cells were treated with $1,5,10,20,30,40,50,60$, and $70 \mu \mathrm{M}$ CDDP for $24 \mathrm{~h}(\mathrm{~A})$ or $10 \mu \mathrm{M}$ CDDP for $24 \mathrm{~h}, 48 \mathrm{~h}$ and $72 \mathrm{~h}$ (B). The survival rates following treatment were detected by CCK8 assay. Results represent the mean +/- SD of triplicate wells and are representative of at least three independent experiments. The survival rates of ART1-shRNA cells were statistically lower than in the untransfected and control-shRNA cells under all of the conditions tested $(* \mathrm{P}<0.05)$.

Western blot analysis of untransfected, control shRNA and ART1-shRNA CT26 cell groups either with or without CDDP treatment. Akt expression was not statistically different between the three cell groups for either untreated or CDDP treated cells. However, phosAkt Thr ${ }^{308}$ expression was significantly decreased in ART1-shRNA cells compared to controlshRNA cells and untransfected cells, for both untreated and CDDP treated cells $(\mathrm{P}<0.05)$ (Fig. 4 , first two rows). Because Akt is primarily considered an inducer of cell survival [30, 31], the decrease in Akt activation in ART1 knockdown cells could provide an explanation for their reduced cell survival.

The activation of the NF- $\mathrm{B}$ pathway is also often associated with cell survival [32] and is a downstream mediator of the Akt pathway. To assess the possible role of the NF$\kappa B$ pathway in ART1-dependent cell survival, we investigated the levels of phosphorylated $\mathrm{I} \kappa \mathrm{B} \alpha$ and the total and nuclear levels of NF- $\mathrm{B}$ p 65 by Western blot analysis. Our results demonstrated that whether exposed to CDDP or not, the levels of phos-IкB $\alpha$ in ART1-shRNA cells were reduced (Fig. 4). Additionally, the nuclear levels of NF- $\mathrm{KB}$ p 65 were reduced, while the total NF- $\mathrm{BB}$ p65 expression did not change significantly in ART1-shRNA cells compared with other two groups. These results suggest that ART1 silencing leads to a reduction in the activation and nuclear translocation of NF- $\mathrm{KB}$ p65, providing additional support for the role of ART1 in regulating cell survival signaling cascades.

ART1 silencing decreases Bcl-xl and Bcl-2 protein expression and increases Bax protein expression

The Bcl2 family of proteins has an integral role in regulating apoptosis and, like the NF$\kappa \mathrm{B}$ family, is known to be regulated by Akt signaling. To determine whether ART1 knockdown in CT26 cells affects the expression of Bcl2 family proteins, we performed Western blotting for the anti-apoptotic family members Bcl-2 and Bcl-xl and the pro-apoptotic family member Bax. The expression of Bcl-2 and Bcl-xl was reduced in ART1-shRNA CT26 cells compared to the control-shRNA and untransfected groups, both for cells with and without CDDP treatment. Conversely, expression of the pro-apoptotic protein Bax was elevated compared to the two control groups $(\mathrm{P}<0.05)$ (Fig. 5). These results provide further support for the role of the Akt pathway and suggest a molecular mechanism by which ART1 may regulate apoptotic cell death. 


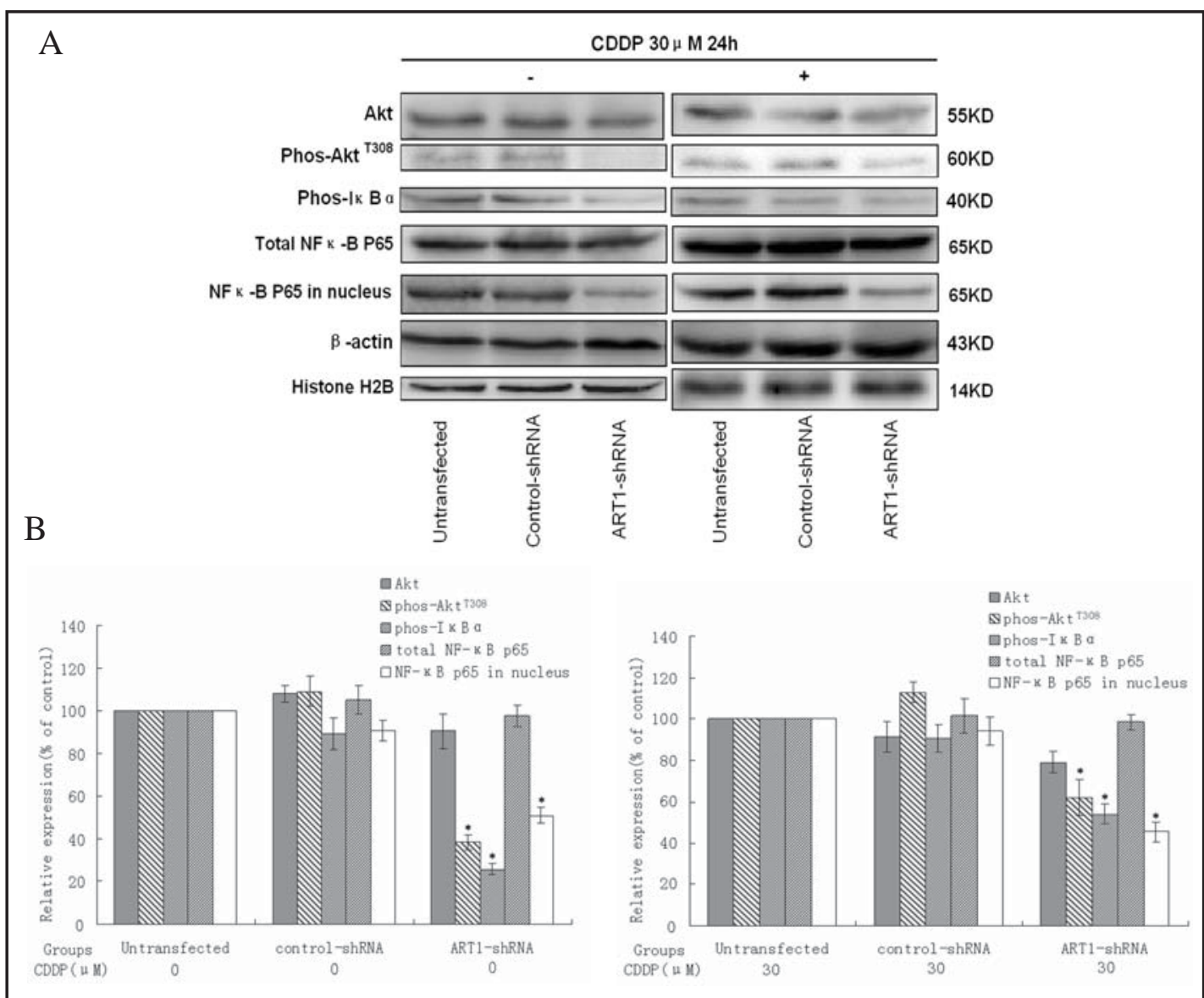

Fig. 4. ART1 silencing reduces the activation of the Akt and NF- $\kappa B$ pathways in CT26 cells. (A) Untransfected, control-shRNA and ART1-shRNA CT26 cells were treated with $30 \mu \mathrm{M}$ CDDP for $24 \mathrm{~h}$. Protein levels were determined by Western blotting. Representative images are shown. (B) Quantification of protein levels was performed by densitometry. Results represent the mean +/- SD of the expression levels from three independent experiments standardized to $\beta$-actin expression (or to histone $\mathrm{H} 2 \mathrm{~B}$ expression for nuclear $\mathrm{NF}-\mathrm{\kappa B}$ ) and normalized to $100 \%$ in untransfected cells. Expression of phospho-Akt T308 and phospho$\mathrm{I} \kappa \mathrm{B} \alpha$ is statistically reduced in the ART1-shRNA group compared with other two groups, while Akt shows a slight reduction, which is not statistically significant. Furthermore, the expression of nuclear NF- $\kappa \mathrm{B}$ p65 is lower in the ART1-shRNA group, while the expression of total NF- $\kappa B$ p65 is not. $\left({ }^{*} \mathrm{P}<0.05\right.$ relative to the expression in untransfected and control-shRNA cells).

\section{Inhibition of Akt signaling regulates $N F-\kappa B$ and Bcl-2 family activation}

To verify the role of Akt in regulating NF- $\mathrm{KB}$ and Bcl-2 pathway activation, we treated CT26 cells with the specific PI3K/Akt pathway inhibitor, $30 \mu \mathrm{M}$ LY294002, either alone or in combination with CDDP. Western blotting demonstrated that LY294002 inhibits Akt phosphorylation, verifying the activity of this inhibitor. The expression of phosphorylated

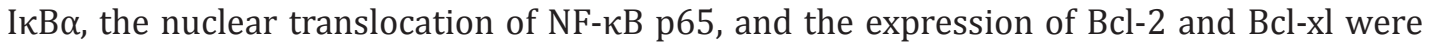
also inhibited, while the expression of Bax was enhanced (Fig. 6)]. Meanwhile, the expression of ART1 did not change significantly. These results provide additional verification of the Akt pathway locates in the downstream of ART1 and NF- $\mathrm{kB} / \mathrm{Bcl}-2$ pathways as downstream regulators of Akt signaling. 


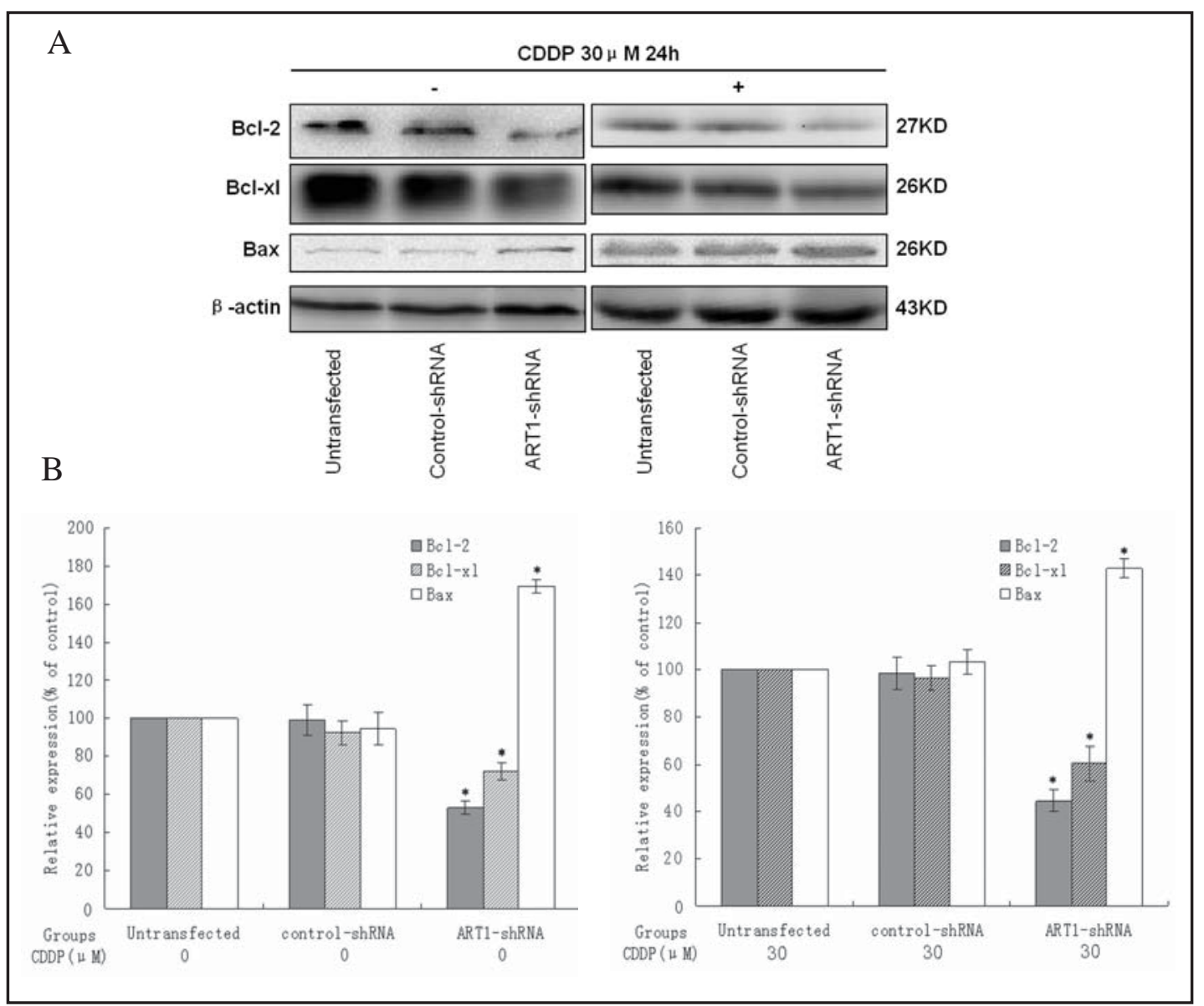

Fig. 5. ART1 silencing leads to modulated expression of Bcl-2, Bcl-xl and Bax. (A) Untransfected, control-shRNA and ART1-shRNA CT26 cells were treated with $30 \mu \mathrm{M}$ CDDP for $24 \mathrm{~h}$. Protein levels were determined by Western blotting, and representative images are shown. (B) Quantification of protein levels was performed by densitometry. Results represent the mean +/- SD of the expression levels from three independent experiments standardized to $\beta$-actin expression and normalized to $100 \%$ in untransfected cells. The expression of Bcl-2 and Bcl-xl are statistically decreased in the ART1-shRNA group compared with other two groups, while the expression of Bax is statistically increased. $(* \mathrm{P}<0.05$ relative to the expression in untransfected and control-shRNA cells).

\section{Discussion}

As a representative ecto-ART family protein, ART1 is reported to play a crucial role in the anti-inflammatory and cytokine secretion capacity of respiratory tract epithelial cells. ART1 also has been linked with proliferation in mouse colorectal carcinoma CT26 cells and angiogenesis in human colorectal carcinoma tissues[18, 21]. However, prior to this study, no data were available to suggest a role for ART1 in the survival and apoptosis of tumor cells. Only a few studies on the related homogeneous arginine-specific mono (ADPribosyl) transferases were suggestive of a function for this family in regulating cell death: the arginine-specific mono (ADP-ribosyl) transferase ART2, which is similar in structure to ART1 but only exists in the mouse, has a cytotoxicity function in T lymphocytes and plays a role in apoptosis in NAD+ dependent immunological reactions [33]; furthermore, the arginine-specific mono Clostridium botulinum (ADP-ribosyl) transferase, C2 toxin delays the apoptosis of mammalian cells [34]. Given that NAD+ serves as an obligatory substrate in ADP-ribosylation reactions and that the concentration of extracellular NAD+ is very 


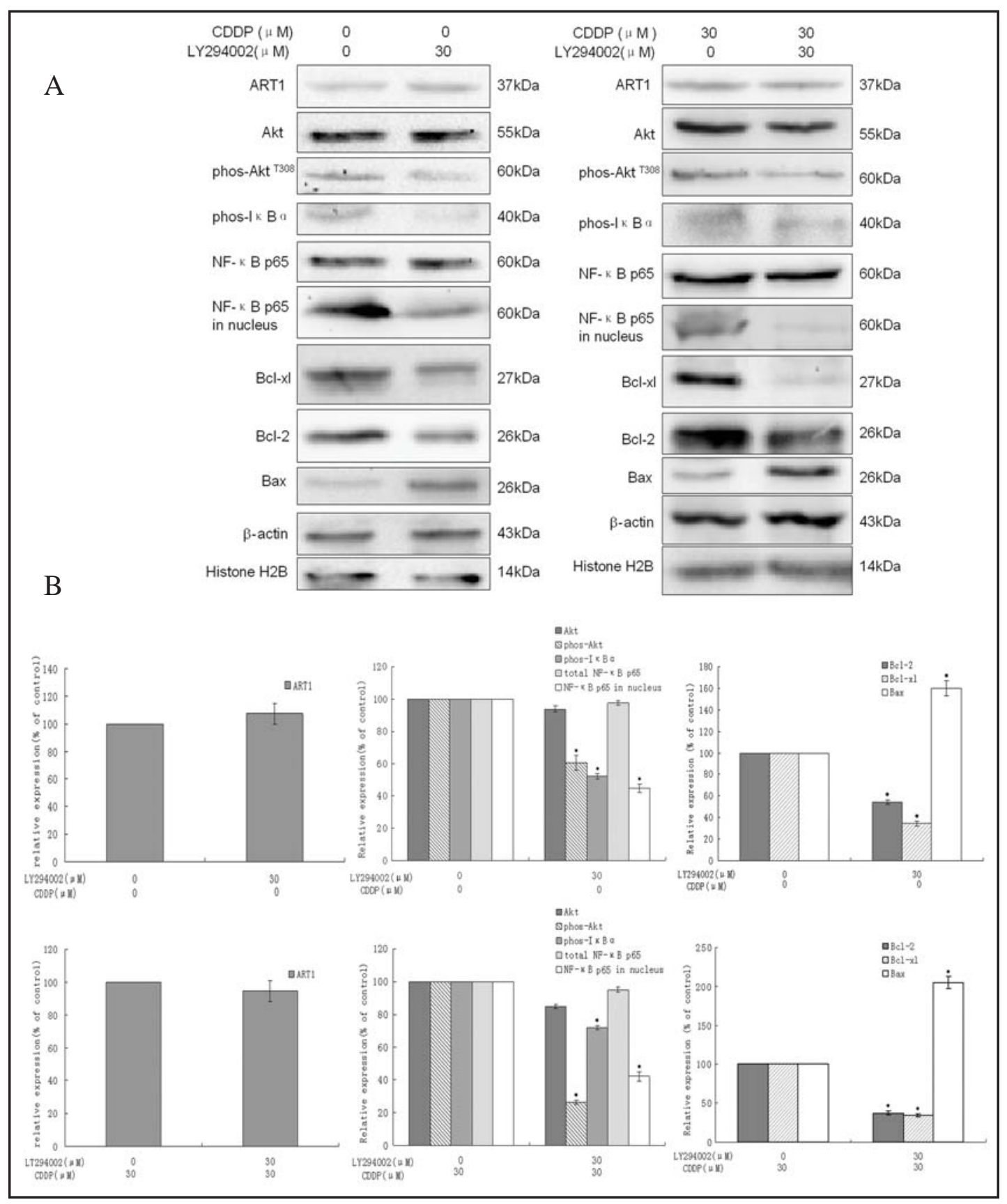

Fig. 6. Inhibition of PI3K/Akt pathway activity leads to reduced NF- $\mathrm{KB}$ and Bcl-2 pathway activation in CT26 cells. (A) CT26 cells were treated with $30 \mu \mathrm{M}$ of the PI3K/Akt pathway inhibitor LY294002 in the absence or presence of CDDP for $24 \mathrm{~h}$. Protein levels were determined by Western blotting. Representative images are shown. (B) Quantification of protein levels was performed by densitometry. Results represent the mean +/$\mathrm{SD}$ of the expression levels in three independent experiments standardized to $\beta$-actin expression (or to histone H2B expression for nuclear NF- $\mathrm{B}$ ) and normalized to 1 in cells without LY294002. The protein levels of phos-AktT308, phospho-I $\kappa \mathrm{B} \alpha$, nuclear NF- $\kappa \mathrm{B}$ p65, Bcl-2 and Bcl-xl were significantly decreased by the addition of LY294002, while the expression of Bax was significantly increased. Expression of ART1, Akt and total NF- $\kappa$ B p65 did not change statistically. ( ${ }^{*} \mathrm{P}<0.05$ relative to the expression in the absence of LY294002).

low under normal physiological conditions, a number of studies have presumed that the main role of ecto-ARTs is to ribosylate ADP and regulate the function of certain membrane 


\section{Cellular Physiology and Biochemistry}

Cell Physiol Biochem 2013;32:1587-1599

\begin{tabular}{l|l}
\hline DOI: $10.1159 / 000356595$ & (C) 2013 S. Karger AG, Basel
\end{tabular}

www.karger.com/cpb

Xiao et al.: ART1 Silencing Enhances Apoptosis of CT26

receptors in response to elevated levels of NAD+ [3]. However, another report relating to ART1 function in regulating the only identified cell surface target integrin $\alpha 7 \beta 1$ showed that micromolar NAD+ concentrations lead to increased binding of the $\alpha 7 \beta 1$ dimer to its target protein laminin, while $100 \mu \mathrm{M} N A D+$ concentration inhibits the activity of integrin $\alpha 7 \beta 1[30]$. Our present study shows that the ART1-shRNA cells have reduced survival rates as compared to the two control groups. Furthermore, Hoechst33342 and Annexin V-PE/7AAD staining confirmed that the reduction in survival for ART1-shRNA CT26 cells is caused by an increased rate of apoptosis. Therefore, we propose that ART1 silencing significantly sensitizes mouse colorectal carcinoma CT26 cells to CDDP-induced apoptosis.

To understand the underlying mechanisms of increased apoptosis in the ART1-shRNA CT26 cells, we investigated the expression and activity of the PI3K/Akt pathway. The PI3K/ Akt pathway is widely accepted to provide a central molecular signal, which promotes cell survival and protects cells from apoptosis $[31,35]$. Akt is also an important downstream signal transducer of integrin $\alpha 7 \beta 1$ [36], and therefore, we speculate that ART1 may regulate tumor cell apoptosis through the PI3K/Akt pathway. Phosphorylation of the $\mathrm{Thr}^{308}$ residue of Akt is enacted by PI3K-dependent kinase 1 (PDK1) and is an indirect measure of PI3K activity [28]; increases in Akt ${ }^{\text {Thr308 }}$ phosphorylation imply the augmentation of the PI3K pathway $[29,37]$. We showed that ART1-shRNA cells have reduced levels of phos-Akt Thr308 in the absence or presence of CDDP. These data directly indicate that ART1 silencing inhibits the activation of the Akt pathway, suggesting that the inhibition of Akt might play a role in potentiating apoptosis by ART1 silencing in CT26 cells.

Themechanisms by which Akt protects CT26 cells from death arelikely to be multifactorial: Akt could directly regulation Bcl-2 related protein, Bad, or affects the transcriptional response to apoptotic stimuli by targeting the Forkhead factors or transcription factor NF$\kappa \mathrm{B}$ in a number of studies and a variety of cells $[22,38]$. NF- $\kappa B$ is most commonly composed of a heterodimer of p50 and p65. The p65 monomer carries a nuclear localization signal; however, cytoplasmic binding by the NF- $\mathrm{BB}$ inhibitor, I $\mathrm{KB} \alpha$ prevents the heterodimer from translocating into the nucleus. Upon activation, IKB kinase (IKK) [39-41]induces the phosphorylation and degradation of IКB $\alpha$, releasing p65 and p50 from the cytoplasm [39, $42]$ so that they are free to translocate into the nucleus and regulate the expression of a wide variety of target genes. Therefore, the phosphorylation/degradation of IкB and the nuclear translocation of NF- $\kappa B$ p 65 are common indicators of NF- $\kappa B$ activation. In the present study, we demonstrate that Akt and NF- $\mathrm{KB}$ are coregulated by ART1. Effects on the NF- $\mathrm{KB}$ pathway are verified by examining both phos-IкB degradation and NF- $\kappa \mathrm{B}$ translocation in response to CDDP. Furthermore, we demonstrate that pharmacological inhibition of the Akt pathway leads to reduced NF- $\mathrm{KB}$ activity. Therefore, effects on NF- $\mathrm{KB}$ are likely, at least in part, to explain the Akt-dependent effects in ART1-shRNA CT26 cells.

The protective role of Akt in CT26 cells is also likely to be explained by effects on the Bcl-2 family proteins. The expression of the classical anti-apoptotic proteins, Bcl-2 and Bcl$\mathrm{xl}$ is regulated by NF- $\kappa \mathrm{B}$, while the pro-apoptotic protein Bax is regulated by Akt through the transcription factor p53 [42-44]. Bcl-2 is an oncogene product that appears to be at the convergence of many apoptotic pathways, while Bax encodes a dominant inhibitor of Bcl-2 [45-47]. The ratio of Bcl-2 to Bax at the effector phase may serve as the final determinant as to whether a cell enters the apoptosis cycle $[48,49]$. Decreased Bcl-xl levels also lead to an increasing tendency of apoptosis, while high expression of the Bcl-xl gene is correlated with lower apoptotic capability [50,51]. We demonstrated that in ART1-shRNA cells, the expression of Bcl-2 and Bcl-xl are visibly decreased, while the expression of Bax is increased. This would lead to a lower Bcl-2/Bax ratio than in untransfected and control-shRNA CT26 cells. Therefore, modulation of the Bcl-xl expression and Bcl-2/Bax ratio caused by the reduction in NF- $\kappa \mathrm{B}$ activation may contribute to the increased apoptosis in ART1-shRNA CT26 cells through its effects on the PI3K/Akt pathway.

To mimic the inhibition of Akt activity in ART1-shRNA cells, LY294002, a highly efficacious inhibitor of the PI3K/Akt pathway, was applied to CT26 cells alone or combined with CDDP [52]. The inhibitory effect on NF- $\mathrm{KB}$ and Bcl-2 signaling activity by LY294002 


\section{Cellular Physiology and Biochemistry}

Cell Physiol Biochem 2013;32:1587-1599

\begin{tabular}{l|l}
\hline DOI: $10.1159 / 000356595$ & (C) 2013 S. Karger AG, Basel
\end{tabular}

\begin{tabular}{l|l} 
Published online: December 03, 2013 & www.karger.com/cpb \\
\hline
\end{tabular}

Xiao et al.: ART1 Silencing Enhances Apoptosis of CT26

was similar to that achieved by ART1 silencing. Besides, inhibition of Akt by LY294002 failed to bring significant change to ART1 expression. These further support the role of the Akt pathway, the nuclear translocation of NF- $\mathrm{BB}$ and the modulation of $\mathrm{Bcl}-2$ family protein expression in the enhancement of apoptosis mediated by ART1 silencing.

Because PI3K/Akt is not the ultimate and sole pathway in tumor cell survival, further studies on other pathways may reveal the importance of additional mechanisms of ART1 silencing in apoptosis. For example the ERK pathway, which encompasses more complexity than the PI3K/Akt pathway because of its pro- or anti-apoptosis effect in different cancer cells and in response to different apoptotic inducing agents [53-55], might be explored as an additional target of ART1. Furthermore, the Rho signal pathway is also an important downstream pathway of the ART1-integrin $\alpha 7$ 1 reaction, which plays an important role in cytoskeleton regulation [56]. In addition, further research assessing the changes in NAD+ levels in the extracellular compartment in response to ART1 enzymatic activity is an important question that has not yet been addressed. In view of the wealth of research questions that remains to be answered in the field of oncotherapy, we hope that this experimental study begins to elucidate a role for ART1 inhibitors as a promising therapeutic strategy for colorectal carcinoma.

\section{Conflict of Interest}

The authors declare no conflict of interest.

\section{Acknowledgements}

This research was supported by grants from the Ministry of Education Specialized Research Fund for the Doctoral Program of Higher Education (Grant No. 20105503110009) and the Science and Technology Project of the Education Commission of Chongqing (Grant No. KJ110322).

\section{References}

1 Wolpin BM, Mayer RJ: Systemic treatment of colorectal cancer. Gastroenterology 2008;134:1296-1310. e1291.

2 Fuertes MA, Alonso C, Pérez JM: Biochemical modulation of cisplatin mechanisms of action: Enhancement of antitumor activity and circumvention of drug resistance. Chem Rev 2003;103:645-662.

-3 Ueda K, Hayaishi O: Adp-ribosylation. Annu Rev Biochem 1985;54:73-100.

4 Braren R, Glowacki G, Nissen M, Haag F, Koch-Nolte F: Molecular characterization and expression of the gene for mouse nad+: Arginine ecto-mono (adp-ribosyl) transferase, art1. Biochem J 1998;336:561.

5 Glowacki G, Braren R, Firner K, Nissen M, Kühl M, Reche P, Bazan F, Cetkovic-Cvrlje M, Leiter E, Haag F: The family of toxin-related ecto-adp-ribosyltransferases in humans and the mouse. Protein Sci 2002;11:16571670.

-6 Graves DJ, Huiatt TW, Zhou H, Huang H-Y, Sernett SW, Robson RM, McMahon KK: Regulatory role of arginine-specific mono (adp-ribosyl) transferase in muscle cellsAdv Exp Med Biol 1997;419:305-313.

-7 Herrero-Yraola A, Bakhit SM, Franke P, Weise C, Schweiger M, Jorcke D, Ziegler M: Regulation of glutamate dehydrogenase by reversible adp-ribosylation in mitochondria. EMBO J 2001;20:2404-2412.

8 Jorcke D, Ziegler M, Herrero-Yraola A, Schweiger M: Enzymic, cysteine-specific adp-ribosylation in bovine liver mitochondria. Biochem J 1998;332:189-193.

9 Li P-L, Chen C-L, Bortell R, Campbell WB: 11, 12-epoxyeicosatrienoic acid stimulates endogenous monoadp-ribosylation in bovine coronary arterial smooth muscle. Circ Res 1999;85:349-356. 


\section{Cellular Physiology and Biochemistry}

Cell Physiol Biochem 2013;32:1587-1599

\begin{tabular}{l|l}
\hline DOI: $10.1159 / 000356595$ & (C) 2013 S. Karger AG, Basel
\end{tabular}

Published online: December 03, $2013 \quad$ www.karger.com/cpb

Xiao et al.: ART1 Silencing Enhances Apoptosis of CT26

10 Liszt G, Ford E, Kurtev M, Guarente L: Mouse sir2 homolog sirt6 is a nuclear adp-ribosyltransferase. J Biol Chem 2005;280:21313-21320.

-11 Lupi R, Dani N, Dietrich A, Marchegiani A, Turacchio S, Berrie C, Moss J, Gierschik P, Corda D, Girolamo M: Endogenous mono-adp-ribosylation of the free $\mathrm{g} \beta \gamma$ prevents stimulation of phosphoinositide 3-kinase- $\gamma$ and phospholipase c- $\beta 2$ and is activated by g-protein-coupled receptors. Biochem J 2002;367:825-832.

12 Tanner KG, Landry J, Sternglanz R, Denu JM: Silent information regulator 2 family of nad-dependent histone/protein deacetylases generates a unique product, 1-o-acetyl-adp-ribose. Proc Natl Acad Sci USA 2000;97:14178-14182.

13 Terashima M, Yamamori C, Tsuchiya M, Shimoyama M: Adp-ribosylation of tubulin by chicken nad-arginine adp-ribosyltransferase suppresses microtubule formation. J Nutr Sci Vitaminol (Tokyo) 1999;45:393-400.

14 Okazaki IJ, Zolkiewska A, Nightingale MS, Moss J: Immunological and structural conservation of mammalian skeletal muscle glycosylphosphatidylinositol-linked adp-ribosyltransferases. Biochemistry 1994;33:12828-12836.

15 Haag F, Koch-Nolte F, Kühl M, Lorenzen S, Thiele H-G: Premature stop codons inactivate the rt6 genes of the human and chimpanzee species. J Mol Biol 1994;243:537-546.

16 Seman M, Adriouch S, Haag F, Koch-Nolte F: Ecto-adp-ribosyltransferases (arts): Emerging actors in cell communication and signaling. Curr Med Chem 2004;11:857-872.

17 Zolkiewska A, Nightingale MS, Moss J: Molecular characterization of nad: Arginine adp-ribosyltransferase from rabbit skeletal muscle. Proc Natl Acad Sci USA 1992;89:11352-11356.

18 Yang LWY-l, Sheng Y-t,Xiong W, Xu J-x,Tang Yi, Li X: The correlation of art1 expression with angiogenesis in colorectal carcinoma and it relationship with vegf and integrin $\alpha v \beta 3$ expressions. Basic Clin Med 2012;32:1064-1069.

19 Balducci E, Micossi LG, Soldaini E, Rappuoli R: Expression and selective up-regulation of toxin-related mono adp-ribosyltransferases by pathogen-associated molecular patterns in alveolar epithelial cells. FEBS Lett 2007;581:4199-4204.

20 Del Vecchio M, Balducci E: Mono adp-ribosylation inhibitors prevent inflammatory cytokine release in alveolar epithelial cells. Mol Cell Biochem 2008;310:77-83.

21 Xu JX, Wang YL, Tang Y, Xiong W: Effect of art1 gene silencing by rna interference on the proliferation of mouse colon carcinoma cells and its possible mechanism. TUMOR 2012;32:949-954.

22 Meier F, Schittek B, Busch S, Garbe C, Smalley K, Satyamoorthy K, Li G, Herlyn M: The ras/raf/mek/erk and pi3k/akt signaling pathways present molecular targets for the effective treatment of advanced melanoma. Front Biosci 2005;10:2986.

23 Vivanco I, Sawyers CL: The phosphatidylinositol 3-kinase-akt pathway in human cancer. Nat Rev Cancer 2002;2:489-501.

24 Ohnishi K, Ota I, Takahashi A, Yane K, Matsumoto H, Ohnishi T: Transfection of mutant p53 gene depresses $\mathrm{x}$-ray-or cddp-induced apoptosis in a human squamous cell carcinoma of the head and neck. Apoptosis 2002;7:367-372.

25 Siddik ZH: Cisplatin: Mode of cytotoxic action and molecular basis of resistance. Oncogene 2003;22:72657279.

26 Devarajan P, Savoca M, Castaneda MP, Park MS, Esteban-Cruciani N, Kalinec G, Kalinec F: Cisplatin-induced apoptosis in auditory cells: Role of death receptor and mitochondrial pathways. Hear Res 2002;174:45-54.

-27 Tang Y, Wang Y-L, Yang L, Xu J-X, Xiong W, Xiao M, Li M: Inhibition of arginine adp-ribosyltransferase 1 reduces the expression of poly (adp-ribose) polymerase-1 in colon carcinoma. Int J Mol Med 2013;32:130.

28 McCubrey JA, Steelman L, Chappell W, Abrams S, Montalto G, Cervello M, Nicoletti F, Fagone P, Malaponte G, Mazzarino M: Mutations and deregulation of ras/raf/mek/erk and pi3k/pten/akt/mtor cascades. Oncotarget 2012;3:954-987.

29 Guertin DA, Sabatini DM: The pharmacology of mtor inhibition. Sci Signal 2009;2:pe24.

-30 Zhao Z, Gruszczynska-Biegala J, Zolkiewska A: Adp-ribosylation of integrin $\alpha 7$ modulates the binding of integrin $\alpha 7 \beta 1$ to laminin. Biochem J 2005;385:309.

-31 Dudek H, Datta SR, Franke TF, Birnbaum MJ, Yao R, Cooper GM, Segal RA, Kaplan DR, Greenberg ME: Regulation of neuronal survival by the serine-threonine protein kinase akt. Science 1997;275:661-665.

-32 Dolcet X, Llobet D, Pallares J, Matias-Guiu X: Nf-kb in development and progression of human cancer. Virchows Arch 2005;446:475-482. 


\section{Cellular Physiology and Biochemistry}

Cell Physiol Biochem 2013;32:1587-1599

\begin{tabular}{l|l}
\hline DOI: $10.1159 / 000356595$ & (C) 2013 S. Karger AG, Basel
\end{tabular}

Xiao et al.: ART1 Silencing Enhances Apoptosis of CT26

-33 Seman M, Adriouch S, Scheuplein F, Krebs C, Freese D, Glowacki G, Deterre P, Haag F, Koch-Nolte F: Nad-induced t cell death: Adp-ribosylation of cell surface proteins by art2 activates the cytolytic p2x7 purinoceptor. Immunity 2003;19:571-582.

34 Heine K, Pust S, Enzenmüller S, Barth H: Adp-ribosylation of actin by the clostridium botulinum c2 toxin in mammalian cells results in delayed caspase-dependent apoptotic cell death. Infect Immun 2008;76:46004608.

-35 Li J, Simpson L, Takahashi M, Miliaresis C, Myers MP, Tonks N, Parsons R: The pten/mmac1 tumor suppressor induces cell death that is rescued by the akt/protein kinase $\mathrm{b}$ oncogene. Cancer Res 1998;58:5667-5672.

-36 Gilcrease MZ: Integrin signaling in epithelial cells. Cancer Lett 2007;247:1-25.

37 Hart JR, Vogt PK: Phosphorylation of akt: A mutational analysis. Oncotarget 2011;2:467.

-38 Downward J: Pi 3-kinase, akt and cell survival: Semin Cell Dev Biol 2004;15:177-182.

39 Li C, Yang Z, Zhai C, Qiu W, Li D, Yi Z, Wang L, Tang J, Qian M, Luo J, Liu M: Maslinic acid potentiates the anti-tumor activity of tumor necrosis factor alpha by inhibiting nf-kappab signaling pathway. Mol Cancer 2010;9:1476-4598.

40 Kane LP, Shapiro VS, Stokoe D, Weiss A: Induction of nf-kappab by the akt/pkb kinase. Curr Biol 1999;9:601-604.

41 Hayden MS, Ghosh S: Shared principles in nf-кb signaling. Cell 2008;132:344-362.

-42 Bentires-Alj M, Dejardin E, Viatour P, Van Lint C, Froesch B, Reed JC, Merville M-P, Bours V: Inhibition of the nf-kappa b transcription factor increases bax expression in cancer cell lines. Oncogene 2001;20:2805.

43 Madrid LV, Wang C-Y, Guttridge DC, Schottelius AJ, Baldwin AS, Mayo MW: Akt suppresses apoptosis by stimulating the transactivation potential of the rela/p65 subunit of nf- $\mathrm{kb}$. Mol Cell Biol 2000;20:16261638.

-44 Franke TF, Hornik CP, Segev L, Shostak GA, Sugimoto C: Pi3k/akt and apoptosis: Size matters. Oncogene 2003;22:8983-8998.

45 Adams JM, Cory S: The bcl-2 protein family: Arbiters of cell survival. Science 1998;281:1322-1326.

46 Brady H, Gil-Gómez G: Bax. The pro-apoptotic bcl-2 family member, bax. Int J Biochem Cell Biol 1998;30:647.

47 Yang J, Liu X, Bhalla K, Kim CN, Ibrado AM, Cai J, Peng T-I, Jones DP, Wang X: Prevention of apoptosis by bcl2: Release of cytochrome $\mathrm{c}$ from mitochondria blocked. Science 1997;275:1129-1132.

-48 Mackey TJ, Borkowski A, Amin P, Jacobs SC, Kyprianou N: Bcl-2/bax ratio as a predictive marker for therapeutic response to radiotherapy in patients with prostate cancer. Urology 1998;52:1085-1090.

-49 Raisova M, Hossini AM, Eberle J, Riebeling C, Wieder T, Sturm I, Daniel PT, Orfanos CE, Geilen CC: The bax/ bcl-2 ratio determines the susceptibility of human melanoma cells to cd95/fas-mediated apoptosis. J Invest Dermatol 2001;117:333-340.

-50 Gross A, McDonnell JM, Korsmeyer SJ: Bcl-2 family members and the mitochondria in apoptosis. Genes Dev 1999;13:1899-1911.

51 Soltani-Arabshahi R, Leboeuf C, Rivet J, Pisonero H, Zhao W-L, Bachelez H, Ameisen JC, Janin A: Bcl-xl gene expression correlated with lower apoptotic cell numbers and shorter progression-free survival in pcfcl. J Invest Dermatol 2009;129:1703-1709.

-52 Vlahos CJ, Matter WF, Hui KY, Brown RF: A specific inhibitor of phosphatidylinositol 3-kinase, 2-(4-morpholinyl)-8-phenyl-4h-1-benzopyran-4-one (ly294002). J Biol Chem 1994;269:5241-5248.

53 Xue L, Murray JH, Tolkovsky AM: The ras/phosphatidylinositol 3-kinase and ras/erk pathways function as independent survival modules each of which inhibits a distinct apoptotic signaling pathway in sympathetic neurons. J Biol Chem 2000;275:8817-8824.

54 Yeh PY, Chuang S-E, Yeh K-H, Song YC, Ea C-K, Cheng A-L: Increase of the resistance of human cervical carcinoma cells to cisplatin by inhibition of the mek to erk signaling pathway partly via enhancement of anticancer drug-induced nfkb activation. Biochem Pharmacol 2002;63:1423-1430.

-55 Zhuang S, Schnellmann RG: A death-promoting role for extracellular signal-regulated kinase. J Pharmacol Exp Ther 2006;319:991-997.

-56 Zaoui K, Honoré S, Isnardon D, Braguer D, Badache A: Memo-rhoa-mdia1 signaling controls microtubules, the actin network, and adhesion site formation in migrating cells. J Cell Biol 2008;183:401-408. 